\title{
WORK RELATED VALUES AND ORGANIZATIONAL COMMITMENT RELATIVE TO GENDER AND AGE
}

\author{
Agnieszka Leszczynska ${ }^{1}$
}

\begin{abstract}
This article discusses issues related to organizational commitment and work related values. The research problem focuses on the correlation between values related to professional work and the affective, normative and calculative commitment of employees. A research question was posed as to what work related values are correlated with organisational commitment. The article presents the results of an empirical study conducted on a group of 2076 people with the use of a diagnostic survey. The obtained data were analysed relative to the gender and age of the respondents. The results indicate certain discrepancies in terms of the value hierarchies observable between employees of different ages. Both men and women selected work-life balance and security as their most important values. The level of commitment was comparable between representatives of the two genders, with the levels observed for normative commitment. Organisational commitment increased with age and was statistically different for the respective age groups. The study confirmed the correlation between the hierarchy of work related values and the level of commitment, as well as the discrepancies in this respect between the respective age and gender groups. The same suggests that there is a need to account for values held by the employees when developing and employing motivational systems and HR practices.
\end{abstract}

JEL Classification Numbers: M12; DOI: http://dx.doi.org/10.12955/cbup.v6.1172

Keywords: values, commitment, organization

\section{Work related values, commitment to work and their relationships - literature review}

Values can be seen as abstract concepts or lasting beliefs, or ideas concerning a person's goals that serve as guiding standards in his or her life. In other words, they describe what is fundamentally important to a person and therefore form a main part of an individual's identity. They are useful indicators of an individual's decisions and actions. The values approach to motivation assumes that people will be motivated by activities and outcomes that they value (Maslow, 1943; Pinder, 1997). Although there has been some disagreement over the distinction between general values and work values, where work values have been defined as the outcomes people desire and feel they should attain through work (Brief, 1998; Cherrington, 1980; Frieze et al., 2006; Nord et al., 1988). Hofstede (1980) believes that work-related values can be interpreted as the extent to which people assign importance to several general job characteristics. Matic (2008) regards work values as qualities that people desire from their work which reflect a correspondence between a need and satisfaction.

Work values shape employees' perceptions of preferences in the workplace, exerting a direct influence on employee attitudes and behaviours (Dose, 1997), job decisions (Judge \& Bretz, 1992; Lofquist \& Dawis, 1971), and perceptions and problem solving (Ravlin \& Meglino, 1987). One persistent distinction in work values is between extrinsic and intrinsic values (Deci \& Ryan, 1985; Porter \& Lawler, 1968; Ryan \& Deci, 2000). Extrinsic work values focus on the consequences or outcomes of work - the tangible rewards external to the individual, such as income, advancement opportunities, and status. In contrast, intrinsic work values focus on the process of work-the intangible rewards that reflect the inherent interest in the work, the learning potential, and the opportunity to be creative (Ryan \& Deci, 2000). Other researchers mention other values such as autonomy in decision making, job stability or security, altruistic rewards such as helping others or contributing to society, social rewards related to interpersonal relationships at work, leisure, which refers to the opportunity for free time, vacation, and freedom from supervision (Herzog, 1982; Johnson, 2002; Miller, Woehr \& Hudspeth, 2002). In the present study, work related values most commonly listed by researchers were considered, including work-life balance, security, good relations with co-workers, responsibility, achievement, intellectual stimulation, autonomy, and power. Organisational commitment refers to the worker's emotional attachment to, identification with, and involvement in, the organisation (Allen \& Meyer, 1990). It is related to but differentiated from the concept of 'the meaning of work', which concerns those aspects of job satisfaction that have to do with intrinsic satisfactions (Barnes-Farrell \& Matthews, 2007).

Meyer and Allen (1991) propose a three-component model of organisational commitment. The threecomponent model distinguishes between affective, continuance and normative commitment. Affective commitment is the emotional attachment to and involvement in the job, whereas continuance commitment is the awareness of the cost involved for the organisation. Lastly, normative commitment

\footnotetext{
${ }^{1}$ Maria Sklodowska Curie University, Faculty of Economics, agnieszka.leszczynska@ poczta.umcs.lublin.pl
} 
is the obligation to continue commitment (Meyer \& Allen, 1991; Meyer et al., 1993). The importance of affective commitment lies in the belief that it shows the strongest positive relationship with desirable outcomes (Eisenberger et al., 1986), such as meaningful work. Organisational commitment can also be described as the employee's feelings of obligation to remain with the organisation. These feelings result from the normative pressures that employees experience (Allen \& Meyer, 1990; Field \& Buitendach, 2011; Viljoen \& Rothmann, 2009). Reviewing the existing literature, the primary antecedents of organisational commitment have been reported to be related to personal characteristics (gender, age), role issues (role-conflict, autonomy), structural conditions (organisational communication, centralisation) and work experiences (leadership, job involvement) (Cohen, 1992).

Values also condition the behaviour and attitude of employees. Several studies have highlighted the importance of value congruence (or value discrepancy) on employees' well-being, job satisfaction, health and performance. Mowday, Steers, and Porter (1979) characterized three factors associated with organisational commitment. The same include having a strong belief in, and acceptance of the organisation's goals and values. Therefore, the acceptance of organisational values is a factor influencing commitment. Maslach and Leiter (1997) developed a model that focuses on the degree of match or mismatch between an employee and six key domains of his or her job environment. The greater the match (or fit) between the person and the job, the greater the likelihood of commitment to work. Values remain one of the key factors. In a study reported by Verplanken (2004), value congruence together with attitudes directly predicted job satisfaction among nurses. Krapić and Barić (2016) confirm that personal and organisational values showed incremental validity in predicting affective, normative and overall organisational commitment. Work related values were stronger predictors of the organisational commitment than personal values.

\section{Data and Methodology}

The aim of this study was to evaluate the correlation between individual, work related values and the level of employee commitment. The following research question was posed: What work related values are correlated with the affective, normative and calculative commitment of employees? In an effort to answer the same, an empirical study was conducted in a group of 2076 randomly selected employees, $49 \%$ of whom were men. The dominant age group was $31-40$ years (30\%), followed by 18 to 30 -yearolds (26\%), and 41 to 50 -year-olds (19\%). The mean age of the respondents was 39.6; the average seniority was 16.6 years with the mean number of years at the presently held position of 7.8 years. Over half of the respondents were employed as specialists (52\%), $28 \%$ held lower-level positions. The study was conducted in the $1^{\text {st }}$ half of 2017 .

The research tool comprised a survey questionnaire which contained questions related to the employees' hierarchies of values and commitment levels. Variables were evaluated using the 5-tier Likert scale (5 corresponded to definite agreement with the statement), as well as on the basis of values selected (indicated) by respondents as the most important according to their respective individual hierarchies. The study focused on 9 work related values: work-life balance, security, good relations with co-workers, responsibility, achievement, intellectual stimulation, autonomy and power. The distinction proposed by Allen and Meyer (1990) was used for the purposes of evaluating commitment. Three types of commitment were identified, namely affective, calculative and normative. Affective commitment relates to the given employee's emotional bond with the organisation. Calculative commitment is of instrumental character and reflects one's belief that the cost of leaving the organisation would be too high and/or that few alternative employment options exist. Normative attachment relates to the sense of a moral obligation of continued employment, which translates into a sense of loyalty towards the organisation.

A Chi-square test and quartile analysis were used for the assessment of the correlation between values and the level of commitment. In the context of values, the analysis entailed selection/non-selection by the respondent of a particular value as important. The level of commitment was limited to quartiles I and IV, i.e. the assessment pertained to quarters of the population characterised, respectively, by the highest and lowest level of commitment.

\section{Results in terms of values}

The respondents deemed the following work-related values as the most important: work-life balance $(38 \%)$, security $(30 \%)$, followed by interpersonal relations with colleagues $(23 \%)$ and responsibility (23\%; Table 1). The fact that values such as achievement and intellectual stimulation ranked lower 
than the above may suggest that the respondents were not particularly oriented towards professional self-fulfilment and the place of work was perceived through the prism of economic stability rather than possibility of career advancement. In terms of gender, women (regardless of age) were more likely to select "work-life balance" as the most important value (women 45\%, men 34\%, Chi squared test significance 0.000). The second most important value was security (34\% men, $28 \%$ women, significance 0.006). In turn, in the male group the most selected answer was responsibility (26\% compared to $21 \%$ in women, significance 0.01 ). The least selected answer in both groups was power (3.5\% for men and $3 \%$ for women, and with no apparent differences between the groups, significance $0.544)$.

\begin{tabular}{|l|c|c|c|c|c|c|c|c|}
\hline \multicolumn{8}{|c|}{ Table 1: Values selected as the most important relative to the age and gender of respondents (in \%) } \\
\hline \begin{tabular}{|l|c|c|c|c|c|c|c|}
\hline \\
Values
\end{tabular} & $\mathrm{F}$ & $\mathrm{M}$ & $\mathrm{F}$ & $\mathrm{M}$ & $\mathrm{F}$ & $\mathrm{M}$ & $\mathrm{F}$ & $\mathrm{M}$ \\
\hline $\begin{array}{l}\text { Good relations } \\
\text { with co-workers }\end{array}$ & $24 \%$ & $17 \%$ & $29 \%$ & $20 \%$ & $28 \%$ & $19 \%$ & $26 \%$ & $28 \%$ \\
\hline Work-life balance & $46 \%$ & $31 \%$ & $51 \%$ & $37 \%$ & $49 \%$ & $34 \%$ & $34 \%$ & $35 \%$ \\
\hline Security & $35 \%$ & $34 \%$ & $41 \%$ & $30 \%$ & $36 \%$ & $20 \%$ & $25 \%$ & $25 \%$ \\
\hline Achievement & $21 \%$ & $18 \%$ & $19 \%$ & $13 \%$ & $6 \%$ & $12 \%$ & $4 \%$ & $3 \%$ \\
\hline Autonomy & $6 \%$ & $6 \%$ & $7 \%$ & $5 \%$ & $5 \%$ & $7 \%$ & $2 \%$ & $3 \%$ \\
\hline $\begin{array}{l}\text { Professional } \\
\text { integrity }\end{array}$ & $10 \%$ & $14 \%$ & $17 \%$ & $16 \%$ & $23 \%$ & $20 \%$ & $19 \%$ & $2 \%$ \\
\hline Power & $5 \%$ & $4 \%$ & $2 \%$ & $3 \%$ & $3 \%$ & $4 \%$ & $3 \%$ & $2 \%$ \\
\hline $\begin{array}{l}\text { Intellectual } \\
\text { stimulation }\end{array}$ & $16 \%$ & $14 \%$ & $20 \%$ & $13 \%$ & $10 \%$ & $9 \%$ & $1 \%$ & $8 \%$ \\
\hline Responsibility & $10 \%$ & $21 \%$ & $21 \%$ & $22 \%$ & $27 \%$ & $30 \%$ & $30 \%$ & $31 \%$ \\
\hline Source: own study & & & & & & & \\
\hline
\end{tabular}

The results of the Chi-square test due to sex indicate that we can reject the hypothesis of the lack of dependence between values, i.e. good relations with co-workers, work-life balance, security, responsibility and gender (significance less than 0,05; Table 2). We should assume that there is a dependency for these variables.

\begin{tabular}{|l|l|c|c|}
\hline Table 2: Pearson's Chi-square (values-gender) \\
\hline & & Value & Asymptotic significance \\
\cline { 2 - 4 } & Good relations with co-workers & 6,92 & 0,09 \\
\cline { 2 - 4 } & Work-life balance & 22,92 & 0,00 \\
\cline { 2 - 4 } & Security & 7,51 & 0,06 \\
\cline { 2 - 4 } & Achievement & 1,87 & 0,17 \\
\cline { 2 - 4 } & Autonomy & 0,011 & 0,917 \\
\cline { 2 - 4 } & Professional integrity & 1,89 & 0,16 \\
\cline { 2 - 4 } & Power & 0,36 & 0,54 \\
\cline { 2 - 4 } & Intellectual stimulation & 1,7 & 0,19 \\
\cline { 2 - 4 } & Responsibility & 6,71 & 0,01 \\
\hline
\end{tabular}

For the respondents holding higher-level positions the most important values included: work-life balance $(9 \%)$, security $(9 \%)$, and responsibility $(7 \%)$, for the lower-level staff these included: worklife balance (22\%), security (16\%), good relations with co-workers (13\%). The managerial staff most commonly selected balance (8\%), security (6\%), and responsibility (5\%). An in-depth analysis and comparison of the respective employee groups indicated that:

1) in terms of the value described as work-life balance, there were differences between lowerlevel positions on the one hand and specialist and managerial staff on the other (the value was lower for lower-level staff and similar for managerial and specialist staff, significance 0.000),

2) the value of power varied between the groups (more important for lower-level positions; significance 0.04). 
In terms of age, the following statistically significant general observations could be made with regard to, respectively:

- good relations with co-workers - the number of indications increased with the age of respondents (significance 0.021),

- the value of work-life balance - the highest number of indications was observed in the 30-49 age group (significance 0.07 ),

- $\quad$ security - the number of indications decreased with age (significance 0.003),

- achievement - the number of indications decreased with age (significance 0.000),

- professional integrity - the number of indications increased with age (excluding the 60+ group, significance 0.000 ).

The obtained results indicate a different hierarchy of work related values in the respective respondent age groups.

The Chi-square test results indicate that there are relationships between age and all values except for autonomy (Table 3).

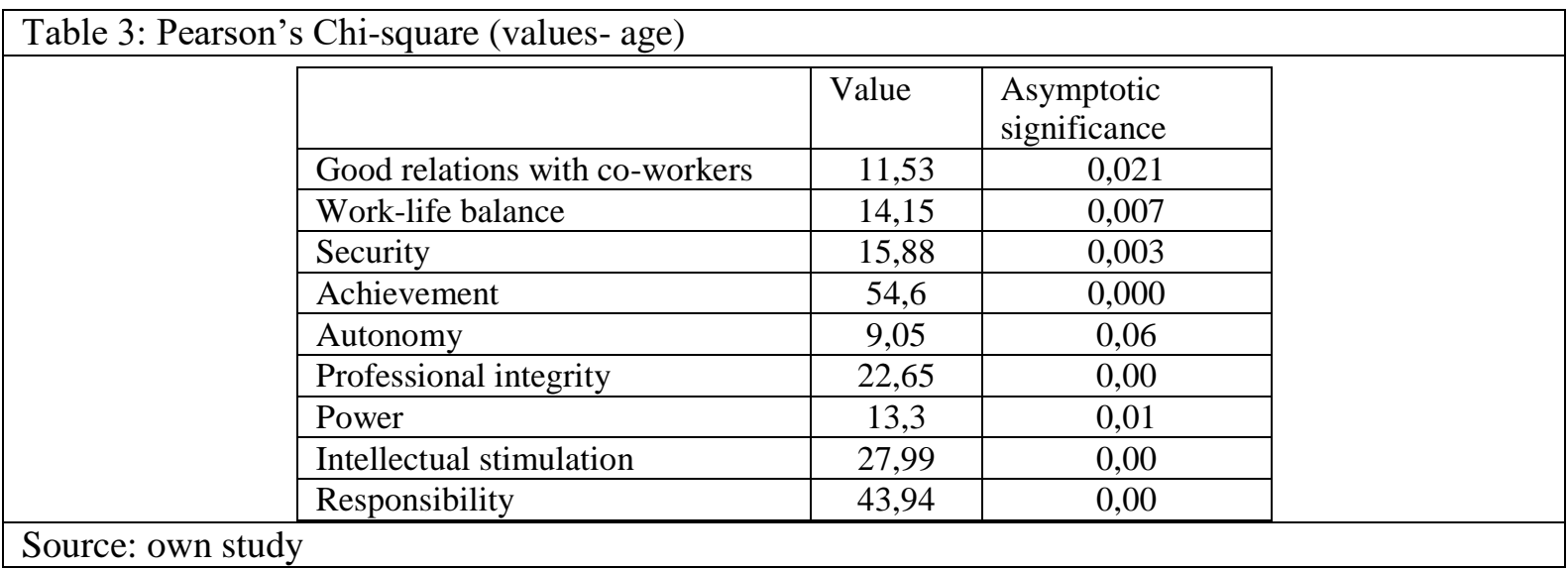

\section{Results in terms of commitment}

The following mean values were obtained (on the scale of 1-5): affective commitment 3.42; calculative commitment 3.26; normative commitment 4.12. In the context of gender, women tended to value normative commitment the most (4.11) and calculative commitment the least (3.21). Men tended to agree the most with statements related to normative commitment (4.13) and the least with those reflecting calculative commitment (3.31). Differences between genders were observed primarily with respect affective and normative commitment (Levene's test significance 0.004 and 0,002 respectively; strong tests for the equality of means). Commitment varies depending on the position held. The highest levels of the same (irrespective of type) are observed in managerial positions, the lowest in lower-level positions. The highest scores were obtained for normative commitment in the groups of specialists (4.12) and managerial staff (4.33), the lowest for calculative commitment in the context of lower-level (3.0) and specialist (3.30) positions. Organisational commitment was observed to increase with age; it was higher in the subsequent age groups. Affective commitment revealed statistically significant differences between the respective age groups (with the exception of the 40-49 and 50+ groups). Analogous results were obtained for normative commitment.

\begin{tabular}{|l|l|l|l|l|}
\hline Table 4: Mean organisational commitment relative to the position held, gender \\
\hline \multicolumn{5}{|l|}{ Organisational commitment } \\
\cline { 2 - 5 } & Employee groups & Affective & Calculative & Normative \\
\cline { 2 - 5 } & Lower-level & 3.19 & 3.00 & 3.98 \\
\cline { 2 - 5 } & Specialist & 3.42 & 3.30 & 4.12 \\
\cline { 2 - 5 } & Managerial & 3.79 & 3.58 & 4.33 \\
\cline { 2 - 5 } & Women & 3.36 & 3.21 & 4.11 \\
\cline { 2 - 5 } & Men & 3.47 & 3.31 & 4.13 \\
\hline
\end{tabular}




\section{Values and commitment in the context of gender and age}

Higher levels of emotional commitment to the company were shown by female respondents who indicated the importance of such values as good relations with co-workers, sense of security, work-life balance, and responsibility (Table 5). Women tended to value a good atmosphere at work and the ability to properly balance personal and professional lives. Normative commitment was also higher in women who were more likely to choose the associated values, although the trend was less evident than in the case of affective commitment.

Table 5: Number of indications of very important values relative to commitment in the groups of men and women

\begin{tabular}{|c|c|c|c|c|c|c|c|c|c|c|c|c|}
\hline & \multicolumn{2}{|c|}{$\begin{array}{l}\text { Aff_commit_ } \\
\text { quart_men }\end{array}$} & \multicolumn{2}{|c|}{$\begin{array}{l}\text { Aff_commit } \\
\text { _quart- } \\
\text { women }\end{array}$} & \multicolumn{2}{|c|}{$\begin{array}{l}\text { Calc_comm } \\
\text { it_quart_me } \\
\text { n }\end{array}$} & \multicolumn{2}{|c|}{$\begin{array}{l}\text { Calc_commit } \\
\text { _quart_wome } \\
\text { n }\end{array}$} & \multicolumn{2}{|c|}{$\begin{array}{l}\text { Norm_commit_ } \\
\text { quart_men }\end{array}$} & \multicolumn{2}{|c|}{$\begin{array}{l}\text { Norm_commit } \\
\text { _quart_wome } \\
\text { n }\end{array}$} \\
\hline & 1.0 & 4.0 & 1.0 & 4.0 & $\begin{array}{l}1.0 \\
\end{array}$ & 4.0 & 1.0 & 4.0 & 1.0 & 4.0 & 1.0 & 4.0 \\
\hline $\begin{array}{l}\text { Good } \\
\text { relations }\end{array}$ & 38 & 99 & 47 & 128 & 55 & 50 & 67 & 55 & 20 & 72 & 20 & 99 \\
\hline $\begin{array}{l}\text { Work-life } \\
\text { balance }\end{array}$ & 81 & 160 & 111 & 178 & 88 & 75 & 119 & 85 & 54 & 87 & 62 & 123 \\
\hline Security & 69 & 123 & 90 & 118 & 85 & 54 & 116 & 52 & 41 & 78 & 49 & 87 \\
\hline $\begin{array}{l}\text { Achieve- } \\
\text { ment }\end{array}$ & 23 & 58 & 37 & 57 & 33 & 21 & 47 & 27 & 14 & 30 & 30 & 35 \\
\hline Autonomy & 14 & 24 & 13 & 24 & 16 & 12 & 22 & 6 & 7 & 19 & 15 & 20 \\
\hline $\begin{array}{l}\text { Professio- } \\
\text { nal integrity }\end{array}$ & 28 & 110 & 20 & 91 & 29 & 56 & 34 & 35 & 5 & 83 & 13 & 72 \\
\hline Power & 13 & 11 & 11 & 13 & 11 & 5 & 15 & 4 & 12 & 7 & 14 & 9 \\
\hline $\begin{array}{l}\text { Intellectual } \\
\text { stimulation }\end{array}$ & 28 & 56 & 37 & 45 & 34 & 21 & 48 & 17 & 12 & 33 & 29 & 29 \\
\hline $\begin{array}{l}\text { Responsi- } \\
\text { bility }\end{array}$ & 48 & 135 & 34 & 104 & 56 & 65 & 46 & 50 & 26 & 93 & 20 & 70 \\
\hline
\end{tabular}

A higher level of affective commitment was observed for men who were more likely to select responsibility, work-life balance, and security as the most important values. This type of commitment was also correlated with the number of indications under autonomy and power, although said values were deemed as unimportant by the respondents. Calculative commitment correlated with the number of indications under responsibility. It was not however, related to security or power at a statistically significant level. In the case of power and autonomy, most respondents perceived those values as unimportant. Normative commitment was higher in men who attributed the greatest importance to relations with co-workers, work-life balance, security, professional integrity, and responsibility.

In the 20-29 age group, affective commitment was related to the number of indications under good relations with co-workers. The respondents also highly valued aspects such as work-life balance, security, and intellectual stimulation, but the correlation of the same with affective commitment was not apparent. Calculative commitment was not found to be correlated with any value. Employees aged between 30 and 39 years who displayed higher levels of commitment were more likely put greater stock in values such as relations with co-workers, work-life balance, and security. Conversely, values that were not perceived as important included autonomy and power. In the context of affective and calculative commitment, the number of indications for power and ability to make decisions increased with the respondents' age. In terms of normative commitment - the highest levels of the same were observed in employees valuing security and professional integrity. In the group of older employees $(50+)$, affective commitment was related to a greater number of indications under values such as worklife balance, responsibility, and relations with co-workers. Among values that were not deemed as important one could list autonomy, achievement, power, and intellectual stimulation. Analogous results were obtained for calculative commitment. Overall, the least significance was attributed to autonomy, achievement, and power, which were not associated with the perceivable benefits of remaining in the organisation. High levels of normative commitment were correlated mostly with indications of professional integrity. Employees aged 50+ attributed high significance to values such as relations with co-workers, work-life balance, and responsibility. The high number of indications under these values corresponded to high levels of normative commitment. 


\section{Conclusions}

The following conclusions can be reached based on the conducted study:

1. younger employees attribute the greatest value to good relations with co-workers. With age, the ability to balance one's professional and personal life and having a sense of security become more important;

2. autonomy and power were not perceived as important values as such, although with age, an observable increase in their influence on the levels of affective and calculative commitment could be observed;

3. employees aged 50+ indicated a very high importance to values such as relations with coworkers, work-life balance, and responsibility. Said values were positively correlated with the level of affective commitment;

4. high levels of normative commitment were mostly correlated with appreciation of professional integrity and responsibility.

In terms of gender, it can be observed that there are no differences between genders where values related to the level of affective commitment are concerned. The same include: responsibility, work-life balance, and security. Calculative commitment in women is correlated with work-life balance and, to a lesser extent, good relations. In men, this type of commitment is affected by the values of work-life balance and responsibility. Therefore, the continued employment (remaining) of men in an organisation is more strongly related to conscientiousness, whereas in the case of women the decisive factor is the atmosphere in the workplace. Normative commitment is, in both genders alike, correlated with work-life balance, good relations, and security, whereby the values tend to be perceived as more important by women.

The conducted research revealed the existence of correlations between one's hierarchy of work related values and the level of commitment on the one hand, and the age and gender on the other. This suggests a need to account for values actually held by employees in organisational motivational systems as well as HR practices. For instance, efforts aimed at shaping affective commitment ought to take into account the implementation of solutions facilitating a better work-life balance and contributing to a greater sense of social security among the employees. Furthermore, organisational value systems also ought to be shaped in such a way so as to correspond to individually prioritised values such as responsibility or professional integrity.

\section{References}

Allen, N. J., \& Meyer, J. P. (1990). The measurement and antecedents of affective, continuance and normative commitment to the organization. Journal of Occupational Psychology, 63, 1-18.

Barnes-Farrell, J. \& Matthews, R. (2007). Age and work attitudes. In K. Shultz \& G. Adams (Editors). Aging and work in the 21 st century (pp. 139-162). Mahwah, NJ : LEA Laurence Erlbaum Associates.

Brief, A. P. (1998). Attitudes in and around organizations. Thousand Oaks, CA: Sage.

Cherrington, D.J. (1980). The work ethic: Working values and values that work. New York: Amacom.

Cohen, J. (1992). A power primer. Psychological Bulletin, 112, 155-159.

Deci, E. L., \& Ryan, R. M. (1985). Intrinsic motivation and self-determination in human behavior. New York: Plenum.

Dose, J. (1997). Work values: An integrative framework and illustrative application to organizational socialization. Journal of Occupational and Organizational Psychology, 70, 219-240.

Dylag, A., Jaworek, M., Karwowski, W., Kozusznik, M., \& Marek, T. Discrepancy between individual and organizational values: Occupational burnout and work engagement among white-collar workers. International Journal of Industrial Ergonomics, 43 (3), 225-231.

Eisenberger, R., Huntington, R., Hutchison, S., \& Sowa, D. (1986). Perceived organizational support. Journal of Applied Psychology, 71(3), 500-507.

Field, L. (2011). Johanna H. Buitendach. Happiness, work engagement and organisational commitment of support staff at a tertiary education institution in South Africa. Journal of Industrial Psychology, 37(1), 1-10.

Frieze,I.H., Olson, J.E., Murrell, A.J., \& Selvan, M.S. (2006). Work Values and Their Effect on Work Behavior and Work Outcomes in Female and Male Managers. Sex Roles, 54(1), 83-93.

Haar, J.M., Russo, M., Suñe, A., \& Ollier-Malaterre, A. (2014). Outcomes of work-life balance on job satisfaction, life satisfaction and mental health: A study across seven cultures. Journal of Vocational Behavior, 85(3).

Herzog, A. R. (1982). High school seniors' occupational plans and values: Trends in sex differences 1976 through 1980. Sociology of Education, 55, 1-13.

Hofstede, G. (1980). Culture's Consequences: National Differences in Thinking and Organizing. Beverly Hills, Calif.: Sage. 
Twenge, J.M., Hoffman, B.J., \& Lance, C.E. (2010). Generational Differences in Work Values: Leisure and Extrinsic Values Increasing, Social and Intrinsic Values Decreasing. Journal of Management, 36(5), 1117-1142.

Huttges, A., Fay, D. (2015). The Gender-Differential Impact of Work Values on Prospects in Research Careers.

Journal of Career Development, 42(6), 524.

Johnson, M. K. (2002). Social origins, adolescent experiences, and work value trajectories during the transition to adulthood. Social Forces, 80, 1307-1341.

Judge, T. A., \& Bretz, R. D., Jr. (1992). Effects of work values on job choice decisions. Journal of Applied Psychology, 77, 261-271.

Krapić, N., \& Barić, S. (2016). Osobne i organizacijske radne vrijednosti kao prediktori odanosti organizacji. Psihologijske teme, 25(3), 479-498.

Koh, Ch.W. (2016). Work-Value Profile and Career Success. University of South Florida, ProQuest Dissertations Publishing.

Lofquist, L. H., \& Dawis, R. V. (1971). Values as second-order needs in the theory of work adjustment. Journal of Vocational Behavior, 12, 12-19.

Maslach, C., \& Leiter, M. P. (1997). The truth about burnout: How organizations cause personal stress and what to do about it. San Francisco: Jossey-Bass.

Maslow, A. H. (1943). A theory of human motivation. Psychological Review, 50, 370-396.

Matic, J. (2008). Cultural differences in employee work values and their implications for management. Management, 13(2), 93-104.

Meyer, J. P., Allen, N. J., \& Smith, C. A. (1993). Commitment to organizations and occupations: Extension and test of a three-component conceptualization. Journal of Applied Psychology, 78(4), 538-551.

Meyer, J. P., \& Allen, N. J. (1991). A three-component conceptualization of organizational commitment. Human Resource Management Review, 1, 61-89.

Miller, M. J., Woehr, D. J., \& Hudspeth, N. (2002). The meaning and measurement of work ethic: Construction and initial validation of a multidimensional inventory. Journal of Vocational Behavior, 60, 451-489.

Mowday, R. T., Steers, R. M., \& Porter, L. W. (1979). The Measurement of Organizational Commitment. Journal of Vocational Behavior, 14, 224-247.

Nord, W. R., Brief, A. P., Atieh, J. M., \& Doherty, E. M. (1988). Work values and the conduct of organizational behavior. In B. M. Staw \& L. L. Cummings (Eds.), Research in organizational behavior (pp. 1- 42). Greenwich, CT: JAI Press.

Pinder, C. C. (1997). Work motivation in organizational behavior. Upper Saddle River, NJ: Prentice Hall.

Porter, L.W., \& Lawler, E. E. (1968). Managerial attitudes and performance. Homewood, IL: Irwin.

Ravlin, E. C., \& Meglino, B. M. (1987). Effect of values on perception and decision making: A study of alternative work values measures. Journal of Applied Psychology, 72, 666-673.

Ryan, R. M., \& Deci, E. J. (2000). Self-determination theory and the facilitation of intrinsic motivation, social development, and well-being. American Psychologist, 55, 68-78.

Selvarajan, T.T., Slattery, J., \& Stringer, D.Y. (2015). Relationship between gender and work related attitudes: a study of temporary agency employees. Journal of Business Research, 68(9), 1919-1927.

Singh, A., \& Gupta, B. (2015). Job involvement, organizational commitment, professional commitment, and team commitment: A study of generational diversity. Benchmarking: An International Journal, 22(6), 1192-1211.

Verplanken, B. (2004). Value congruence and job satisfaction among nurses: a human relations perspective. Int J Nurs Stud., 41(6), 599-605.

Viljoen, J.P., \& Rothmann, S. (2009). Occupational stress, ill health and organisational commitment of employees at a university of technology. Journal of Industrial Psychology, 35(1), 67-78.

Warshawski, S., Barnoy, S., Kagan, I. (2017). Professional, generational, and gender differences in perception of organisational values among Israeli physicians and nurses: Implications for retention. Journal of Interprofessional Care , 31(6), 696-704 